\title{
Comparison of blood pro/antioxidant levels before and after acute exercise in athletes and non-athletes
}

\author{
Dusica Z. Djordjevic ${ }^{1}$, Dejan G. Cubrilo ${ }^{1}$, Nevena S. Barudzic ${ }^{1}$, Milena S. Vuletic ${ }^{1}$, Vladimir \\ I. Zivkovic ${ }^{1}$, Miroslav Nesic ${ }^{1}$, Dragan Radovanovic ${ }^{2}$, Dragan M. Djuric ${ }^{3}$ and Vladimir \\ Lj. Jakovljevic ${ }^{1}$ \\ ${ }^{1}$ Department of Physiology, Faculty of Medicine, University of Kragujevac, Kragujevac, Republic of Serbia \\ ${ }^{2}$ Faculty of Sport and Physical Education, University of Nis, Nis, Republic of Serbia \\ ${ }^{3}$ Institute of Physiology „Richard Burian“, School of Medicine, Belgrade, Republic of Serbia
}

\begin{abstract}
The aims of our study were to assess the redox state of adolescent athletes and non-athletes both at rest and after acute exposure to physical load and to find relations between parameters of redox state and morphofunctional characteristics of subjects. 58 young handball players and 37 non-athletes were subjected to body composition analysis, measuring of maximal oxygen consumption and blood sampling immediately before and after a maximal progressive exercise test. At rest, athletes had significantly higher superoxide dismutase (SOD) and catalase (CAT) activity, higher levels of reduced glutathione (GSH) and nitric oxide (NO) and lower levels of lipid peroxidation (TBARS) compared with non-athletes. A maximal exercise test induced statistically significant rise of superoxide anion radical $\left(\mathrm{O}_{2}{ }^{-}\right)$, hydrogen peroxide $\left(\mathrm{H}_{2} \mathrm{O}_{2}\right)$ and NO levels in non-athletes, while TBARS levels decreased. Athletes experienced the fall in NO levels and the fall in CAT activity. After exercise, athletes had significantly lower levels of $\mathrm{O}_{2}{ }^{-}$compared with non-athletes. Two way repeated measures ANOVA showed that the response of $\mathrm{O}_{2}{ }^{-}, \mathrm{NO}$ and TBARS to the exercise test was dependent on the sports engagement (training experience) of subjects. Significant correlations between morphofunctional and redox parameters were found. These results suggest that physical fitness affects redox homeostasis.
\end{abstract}

Key words: Sports training - Exercise - Oxidative stress - Nitrites - Antioxidant defence

\begin{abstract}
Abbreviations: ADS, antioxidant defense system; CAT, catalase; GSH, reduced glutathione; NBT, nitroblue tetrazolium; $\mathrm{NO}_{2}{ }^{-}$, nitrite; $\mathrm{O}_{2}{ }^{-}$, superoxide anion radical; PRS, phenol red solution; RBCs, red blood cells; RONS, reactive oxygen and nitrogen species; SOD, superoxide dismutase; TBA, thiobarbituric acid; TBARS, thiobarbituric acid reactive substances; TCA, trichloroacetic acid; $\mathrm{VO}_{2} \mathrm{max}$, maximal oxygen consumption.
\end{abstract}

\section{Introduction}

Oxidative stress is a condition in which the delicate balance that exists between production of prooxidants and their subsequent amelioration via the antioxidant defense system (ADS) becomes skewed in favor of prooxidants (Fisher-Wellman and Bloomer 2009). Prooxidants, i.e. reactive oxygen and nitrogen

Correspondence to: Vladimir Jakovljevic, Department of Physiology, Faculty of Medicine, University of Kragujevac, Svetozara Markovica 69, P.P. 124, 34000 Kragujevac, Republic of Serbia E-mail: drvladakgbg@yahoo.com species (RONS), are constantly being generated in the body to a small extent and, since they have a potential to react with a variety of chemical species, they have multiple functions in cell signaling and enzymology (Cooper et al. 2002; Juranek and Bezek 2005; Jacob and Winyard 2009; Powers et al. 2009). On the other hand, excessive RONS production, that appears to be induced by both psychological and physical stress, may lead towards oxidative damage and numerous pathological processes (Møller et al. 1996; Tiidus 1998; Block et al. 2002; Szocs 2004; Dalle-Donne et al. 2006; Valko et al. 2007).

From work over the past three decades, it is clear that exercise of sufficient volume, intensity and duration can lead to an 
increase in RONS production, which may lead to the oxidation of several biological molecules (lipids, proteins, nucleic acids) (Fisher-Wellman and Bloomer 2009). Whether or not this condition is indicative of a harmful stimulus, however, remains a topic of debate (Vollaard et al. 2005). Although exercise-induced RONS production represents a potential detriment to physiological functions, a repeated exposure of the system to increased RONS production from chronic exercise training leads towards positive changes in the body including upregulation of many cell processes and gene expression ( $\mathrm{Al}-$ len and Tresini 2000; Dröge 2002; Ji 2002). According to the principle of hormesis, and basic principle of exercise - stressadaptation, the rise in RONS production represents stimuli for an upregulation in endogenous antioxidant defenses (Finaud et al. 2006; Radak et al. 2008; Fisher-Wellman and Bloomer 2009). This provides adaptive protection from RONS during subsequent training sessions, as well as during non-exercise related conditions (Fisher-Wellman and Bloomer 2009).

It was previously shown that well trained subjects have more efficient ADS compared with sedentary subjects, however, those studies compared only the basal (resting) levels of pro/antioxidants in blood of athletes and non-athletes (Ørtenblad et al. 1997; Balakrishnan and Anuradh 1998; Brites et al. 1999; Evelson et al. 2002; Cazzola et al. 2003; Gougoura et al. 2007; Yamaner 2010). Thus, the primary aim of our study referred to the comparison of the effects of acute maximal intensity exercise on pro/antioxidant response in athletes and non-athletes. We hypothesized that athletes would have not only higher activity of antioxidants in rest, but that the extent of redox disturbance induced by a maximal progressive exercise test would be lower in athletes compared with non-athletes. The secondary aim of our study was to explore the correlations between morphofunctional characteristics of subjects and parameters of redox homeostasis both before and after the exercise test.

\section{Materials and Methods}

\section{Participants}

A group of 58 young handball players (age 16-19 years) and 37 age-matched adolescents who did not perform regular physical activity took part in this research. Athletes were engaged in regular handball (mixed - aerobic-anaerobic) training 5 times a week for $90 \mathrm{~min}$.

Four weeks prior to blood sampling the participants were instructed to abstain from any vitamin or antioxidant dietary supplementation. None of the participants reported any eating disorder, had no ongoing or previous (last half-year) injuries, they were not on any medication known to affect oxidative stress and were non-smokers. They were asked not to engage in any heavy physical activity for $24 \mathrm{~h}$ before the test and not to consume alcohol for $48 \mathrm{~h}$ before the test. To exclude the influence of different dietary intake on nitrite level, all participants were on the same dietary protocol 5 days before the study.

All participants gave a written informed consent (participants under 18 gave the parent's consent). The study was approved by the Ethical committee of Medical Faculty, University of Kragujevac.

\section{Protocol}

The research protocol started at 8 a.m. After participants had filled in the standard sports medicine questionnaire, but before breakfast, a blood sample was taken from their antecubital vein. Then, measurement of body composition was performed using an apparatus for bioelectrical impedance analysis In Body 720 (Biospace, Korea) whose validity was previously confirmed (Lim et al. 2009). Measurement was performed according to manufacturers instructions. Body weight was measured with an accuracy within $0.1 \mathrm{~kg}$ and body fat with an accuracy of $0.1 \%$. Body height was measured by means of an anthropometer (GPM, Switzerland) and the results of the measurements were accurate within $0.1 \mathrm{~cm}$.

After anthropometrical measurement and blood sampling, subjects were subjected to a maximal progressive exercise test on a bicycle ergometer AX1 (Kettler, Germany). Subjects were familiarized to testing procedure. The saddle height was adjusted for each subject and the load was set to $2 \mathrm{~W} / \mathrm{kg}$. The load was increased by $50 \mathrm{~W}$ every $3 \mathrm{~min}$ until the end of the exercise test. Subjects were instructed to ride at $60 \mathrm{rpm}$. Oxygen uptake was determined using an automated cardiopulmonary exercise system (FitMate Pro, Cosmed, Italy) which was calibrated prior to data collection. The validity, reliability, and accuracy of the FitMate gas analyzer were previously reported (Nieman et al. 2006, 2007). We hypothesized that the maximal oxygen consumption $\left(\mathrm{VO}_{2} \mathrm{max}\right)$ was reached when the oxygen consumption reached its plateau (when an increase in workload cannot induce an increase in oxygen consumption) (Howley et al. 1995). The participants stated their subjective feeling of exhaustion by using Borg's CR10 exhaustion scale of at least 8 (Borg 1982).

\section{Biochemical assays}

Blood samples were taken from an antecubital vein into Vacutainer test tube containing sodium citrate anticoagulant. Blood samples were analyzed immediatelly. Blood was centrifuged to separate plasma and red blood cells (RBCs). Biochemical parameters were measured spectrophotometrically.

\section{Superoxide anion radical determination}

The level of superoxide anion radical $\left(\mathrm{O}_{2}{ }^{-}\right)$was measured using NBT (nitroblue tetrazolium) reaction in TRIS-buffer 
combined with plasma samples and read at $530 \mathrm{~nm}$ (Auclair and Voisin 1985).

\section{Hydrogen peroxide determination}

The protocol for measurement of hydrogen peroxide $\left(\mathrm{H}_{2} \mathrm{O}_{2}\right)$ is based on oxidation of phenol red in the presence of horseradish peroxidase (POD; Pick and Keisari 1980). 200 $\mu \mathrm{l}$ sample with $800 \mu \mathrm{l}$ PRS (phenol red solution) and $10 \mu \mathrm{l}$ POD were combined (1:20). The level of $\mathrm{H}_{2} \mathrm{O}_{2}$ was measured at $610 \mathrm{~nm}$.

\section{Nitric oxide determination}

Nitric oxide (NO) decomposes rapidly to form stable metabolite nitrite/nitrate products. Nitrite $\left(\mathrm{NO}_{2}{ }^{-}\right)$was determined as an index of nitric oxide production with Griess reagent (Green et al. 1982). $0.1 \mathrm{ml} 3 \mathrm{~N}$ PCA (perchloric acid), $0.4 \mathrm{ml}$ $20 \mathrm{mM}$ EDTA (ethylenediaminetetraacetic acid) and $0.2 \mathrm{ml}$ plasma were put on ice for $15 \mathrm{~min}$, then centrifuged $15 \mathrm{~min}$ at $6000 \mathrm{rpm}$. After pouring off the supernatant, $220 \mu \mathrm{l} \mathrm{K}{ }_{2} \mathrm{CO}_{3}$ was added. Nitrites were measured at $550 \mathrm{~nm}$. Distilled water was used as a blank probe.

\section{Index of lipid peroxidation}

The degree of lipid peroxidation in plasma was estimated by measuring of thiobarbituric acid reactive substances (TBARS) using $0.4 \mathrm{ml}$ 1\% TBA (thiobarbituric acid) in 0.05 $\mathrm{NaOH}$ mixed with $0.8 \mathrm{ml}$ of plasma, incubated at $100^{\circ} \mathrm{C}$ for $15 \mathrm{~min}$ and measured at $530 \mathrm{~nm}$. Distilled water was used as a blank probe. TBA extract was obtained by combining $0.8 \mathrm{ml}$ plasma and $0.4 \mathrm{ml} \mathrm{TCA}$ (trichloroacetic acid), then samples were put on ice for 10 minutes, and centrifuged for $15 \mathrm{~min}$ at $6000 \mathrm{rpm}$. This method was described previously (Ohkawa et al. 1979).

\section{Determination of antioxidant enzymes}

Isolated RBCs were washed three times with 3 volumes of ice-cold $0.9 \mathrm{mmol} / 1 \mathrm{NaCl}$ and hemolysates containing about $50 \mathrm{~g} \mathrm{Hb} / \mathrm{l}$ (prepared according to McCord and Fridovich 1969), were used for the determination of catalase (CAT) activity. CAT activity was determined according to Beutler (1982). Lysates were diluted with distilled water (1:7 v/v) and treated with chloroform-ethanol $(0.6: 1 \mathrm{v} / \mathrm{v})$ to remove haemoglobin (Tsuchihashi 1923). Then $50 \mu$ CAT buffer, 100 $\mu \mathrm{l}$ sample and $1 \mathrm{ml} 10 \mathrm{mM} \mathrm{H}_{2} \mathrm{O}_{2}$ were added to the samples. Detection was performed at $360 \mathrm{~nm}$. Distilled water was used as a blank probe. Superoxide dismutase (SOD) activity was determined by the epinephrine method of Misra and Fridovich (1972). $100 \mu$ lysate and $1 \mathrm{ml}$ carbonate buffer were mixed, and then $100 \mu \mathrm{l}$ of epinephrine was added. Detection was performed at $470 \mathrm{~nm}$.

\section{Determination of glutathione}

The level of reduced glutathione (GSH) was determined based on GSH oxidation with 5.5-dithio-bis-6.2-nitrobenzoic acid, using Beutler method (Beutler 1975); the concentration is expressed as nanomoles per milliliter of RBCs.

\section{Statistics}

The statistical analysis was performed with SPSS program 19.0 for Windows. Results are expressed as means \pm standard error of the mean (S.E.M.) Data distribution was checked with the Shapiro-Wilk test and depending on its results the appropriate parametric or nonparametric test was used. The differences between two groups (athletes and controls) were assessed using T-test or Mann Whitney test, while the differences between the values of means from two related samples (before and after the maximal exercise test) were assessed by Paired t-test. To check if exercise-induced changes of biochemical parameters are dependent on sports engagement (training experience), Two-way repeated measures ANOVA was used („exercise test“ was set as within subjects factor and „training experience“ as between subjects factor). Correlation between various variables was found using Bivariate correlation (Pearson's coefficient of correlation).

\section{Results}

Demographic and anthropometric characteristics of participants are shown in Table 1. Athletes had statistically lower

Table 1. Age, training experience and morphological characteristics of the investigated groups

\begin{tabular}{|c|c|c|c|c|c|c|c|c|}
\hline & $\begin{array}{c}\text { Age } \\
\text { (years) }\end{array}$ & $\begin{array}{c}\text { Training experience } \\
\text { (years) }\end{array}$ & $\begin{array}{l}\text { Height } \\
(\mathrm{cm})\end{array}$ & $\begin{array}{l}\text { Weight } \\
(\mathrm{kg})^{\star}\end{array}$ & BMI & $\begin{array}{c}\text { Fat } \\
\%\end{array}$ & $\begin{array}{c}\text { Muscle } \\
\%\end{array}$ & $n$ \\
\hline Controls & $17.5 \pm 0.3$ & - & $185.5 \pm 3.1$ & $81.6 \pm 6.1$ & $23.6 \pm 1.3$ & $17.7 \pm 3.4$ & $39.6 \pm 1.4$ & 19 \\
\hline Athletes & $17.3 \pm 0.2^{\mathrm{a}}$ & $7.8 \pm 0.3$ & $183.8 \pm 0.8^{\mathrm{b}}$ & $80.9 \pm 1.4^{\mathrm{c}}$ & $23.9 \pm 0.3^{\mathrm{d}}$ & $12.0 \pm 0.6^{\mathrm{e}}$ & $50.2 \pm 0.3^{f}$ & 58 \\
\hline
\end{tabular}


Table 2. Functional characteristics of the investigated groups

\begin{tabular}{lcccc}
\hline & $\mathrm{VO}_{2} \max (\mathrm{ml} / \mathrm{kg} / \mathrm{min})$ & Time on test $(\mathrm{min})$ & Workload $(\mathrm{W})$ & $n$ \\
\hline Controls & $39.7 \pm 1.3$ & $9.42 \pm 0.42$ & $250.5 \pm 6.98$ & 19 \\
Athletes & $44.6 \pm 0.9^{\mathrm{a}}$ & $10.57 \pm 0.24^{\mathrm{b}}$ & $280.93 \pm 7.63^{\mathrm{c}}$ & 58 \\
\hline
\end{tabular}

${ }^{\mathrm{a}} p=0.034 ;{ }^{\mathrm{b}} p=0.041 ;{ }^{\mathrm{c}} p=0.030$ (significant $p<0.05$ ); T-test used. Results are presented as mean \pm S.E.M.

percentage of fat and higher percentage of muscle compared with non-athletes.

Athletes also had significantly higher aerobic power compared to non-athletes (Table 2).

At rest, athletes had significantly higher levels of NO $\left(\mathrm{NO}_{2}{ }^{-}\right)$(Fig. 1C), lower levels of TBARS (Fig. 1D), higher activity of SOD (Fig. 2A), higher activity of CAT (Fig. 2B) and higher levels of GSH (Fig. 2C) compared with nonathletes.
The maximal exercise test induced a statistically significant rise of $\mathrm{O}_{2}^{-}$(Fig. 1A), $\mathrm{H}_{2} \mathrm{O}_{2}$ (Fig. 1B) and $\mathrm{NO}\left(\mathrm{NO}_{2}{ }^{-}\right.$) (Fig. 1C) levels in non-athletes and fall of TBARS levels (Fig. 1D), while athletes experienced the decrease in $\mathrm{NO}\left(\mathrm{NO}_{2}^{-}\right)$levels (Fig. 1C) and CAT activity (Fig. 2B) after exercise test.

The differences in levels of pro/antioxidants in blood of athletes and non-athletes after exercise were seen only in case of $\mathrm{O}_{2}^{-}$. Athletes had significantly lower $\mathrm{O}_{2}{ }^{-}$levels compared with non-athletes (Fig. 1A).
A

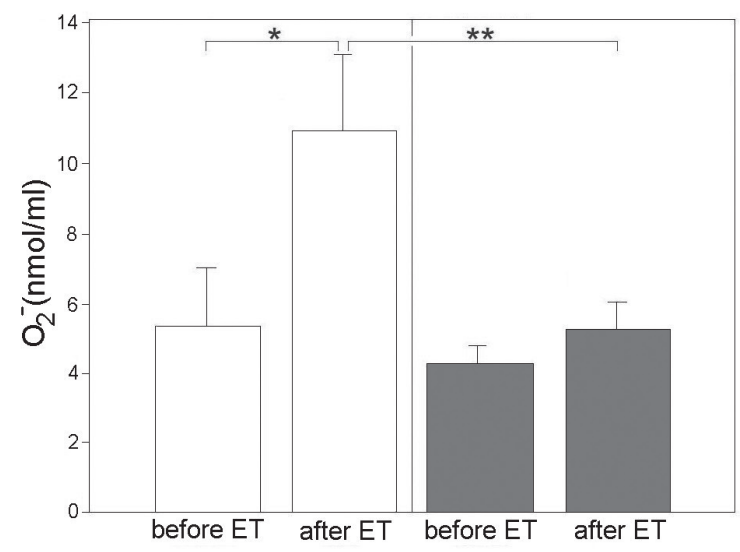

C

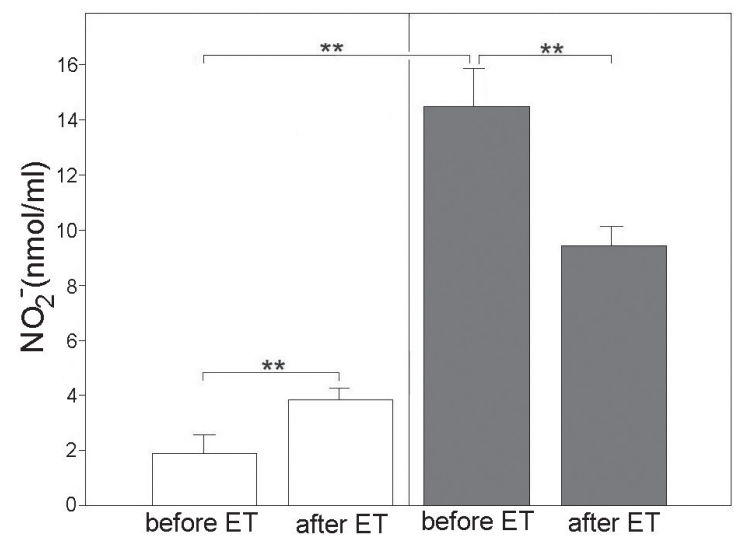

B

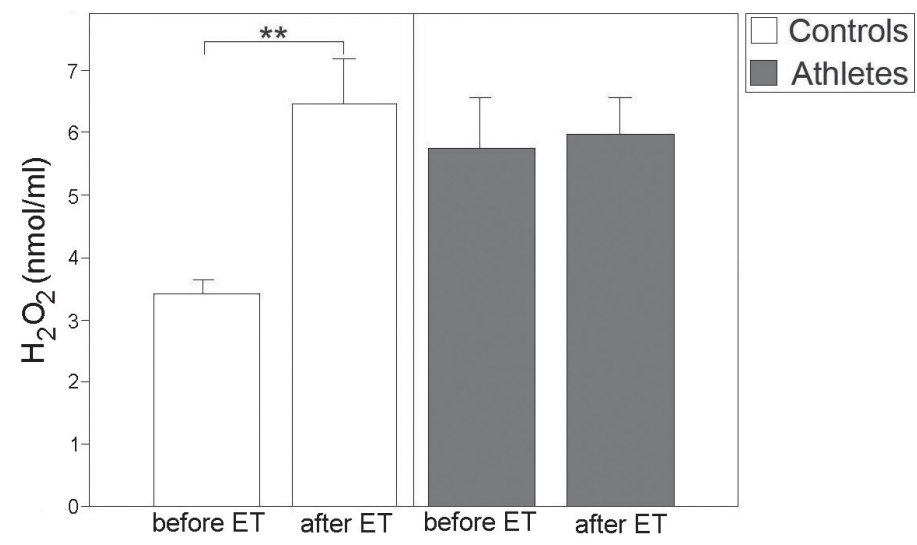

D

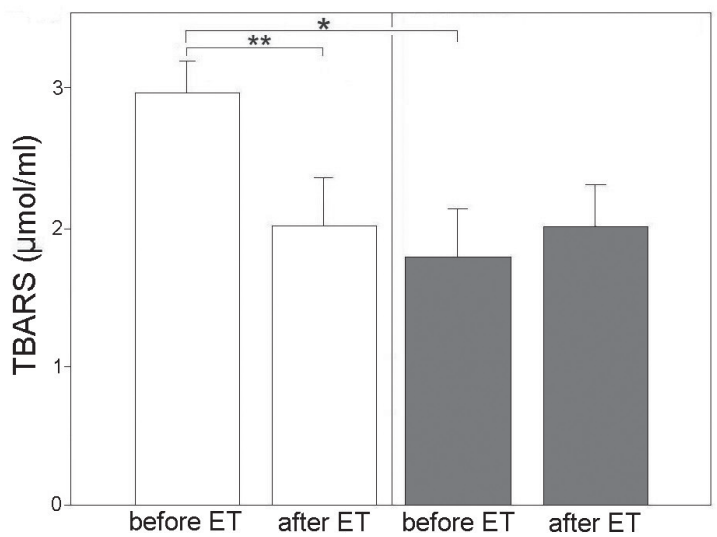

Figure 1. Values of prooxidative parameters: superoxide anion radical $\mathrm{O}_{2}{ }^{-}(\mathbf{A})$, hydrogen peroxide $\mathrm{H}_{2} \mathrm{O}_{2}(\mathbf{B})$, nitrites $\mathrm{NO}_{2}{ }^{-}(\mathbf{C})$ and index of lipid peroxidation TBARS (D) in athletes and controls before and after the exercise test. ${ }^{*} p<0.05$; ${ }^{* *} p<0.01$; ET, exercise test. Data were expressed as mean \pm S.E.M. 
Two-way repeated measures ANOVA showed that sports engagement (training experience) influenced the response of $\mathrm{O}_{2}{ }^{-}$(factor "exercise test" $p=0.001$, combination of factors ,exercise test" and "training experience“ $p=0.007$ ), NO (factor ,exercise test" $p=0.320$, combination of factors "exercise test" and "training experience " $p=0.030$ ), and TBARS (factor „exercise test" $\mathrm{p}=0.084$, combination of factors "exercise test" and "training experience" $p=0.027$ ), to the exercise test (Figs. 1A, 1C and 1D).

The following significant correlations between parameters of body composition (height, weight, body mass index, fat percentage, muscle percentage), parameter of functional capacity $\left(\mathrm{VO}_{2} \mathrm{max}\right)$ and parameters of redox state $\left(\mathrm{O}_{2}{ }^{-}, \mathrm{H}_{2} \mathrm{O}_{2}\right.$, $\mathrm{NO}\left(\mathrm{NO}_{2}{ }^{-}\right)$, TBARS, SOD, CAT, GSH) were found:

- Fat percentage correlated positively with $\mathrm{H}_{2} \mathrm{O}_{2}$ levels both before $(p<0.01 ; \mathrm{r}=0.335)$ and after the exercise test $(p<$ $0.05 ; \mathrm{r}=0.309)$, and with TBARS after the exercise test $(p<0.01 ; \mathrm{r}=0.359)$.

- Muscle percentage correlated negatively with $\mathrm{H}_{2} \mathrm{O}_{2}$ after the exercise test $(p<0.01 ; \mathrm{r}=-0.347)$ and with TBARS after the exercise test $(p<0.05 ; \mathrm{r}=0.323)$.

Following significant correlations between aerobic power and parameters of redox state were found:

- $\mathrm{VO}_{2}$ max correlated negatively with $\mathrm{H}_{2} \mathrm{O}_{2}$ before the exercise test $(p<0.01 ; \mathrm{r}=-0.366)$ and with TBARS both before $(p<0.05 ; \mathrm{r}=-0.328)$ and after the exercise test $(p<0.05 ; \mathrm{r}=-0.279)$.

- $\mathrm{VO}_{2}$ max also correlated negatively with $\mathrm{NO}\left(\mathrm{NO}_{2}{ }^{-}\right)$after the exercise test $(p<0.05 ; \mathrm{r}=-0.295)$.

- The only statistically significant correlation between $\mathrm{VO}_{2}$ max and antioxidant enzymes was found between $\mathrm{VO}_{2}$ max and CAT activity before the exercise test, and the correlation was positive $(p<0.05 ; \mathrm{r}=0.326)$.

\section{Discussion}

Although there is some inconsistency present within the literature, it is clear that both aerobic and anaerobic exercise have the potential to result in increased free radical production, which may or may not result in acute oxidative stress (Fisher-Wellman and Bloomer 2009). The extent of redox homeostasis disturbance induced by an acute bout of exercise depends on many factors, inter alia, exercise mode, intensity and duration, participant's state of training, gender, age and nutritional habits (Fanò et al. 2001; Finaud et al. 2006; Goldfarb et al. 2007). Many studies have compared the antioxidant status of trained and untrained subjects at rest, but, to our knowledge, except the study of Ørtenblad and coworkers (1997) that analysed blood antioxidant status in untrained and jump-trained humans following six bouts of 30 -s continuous jumping, no study has compared the ath-
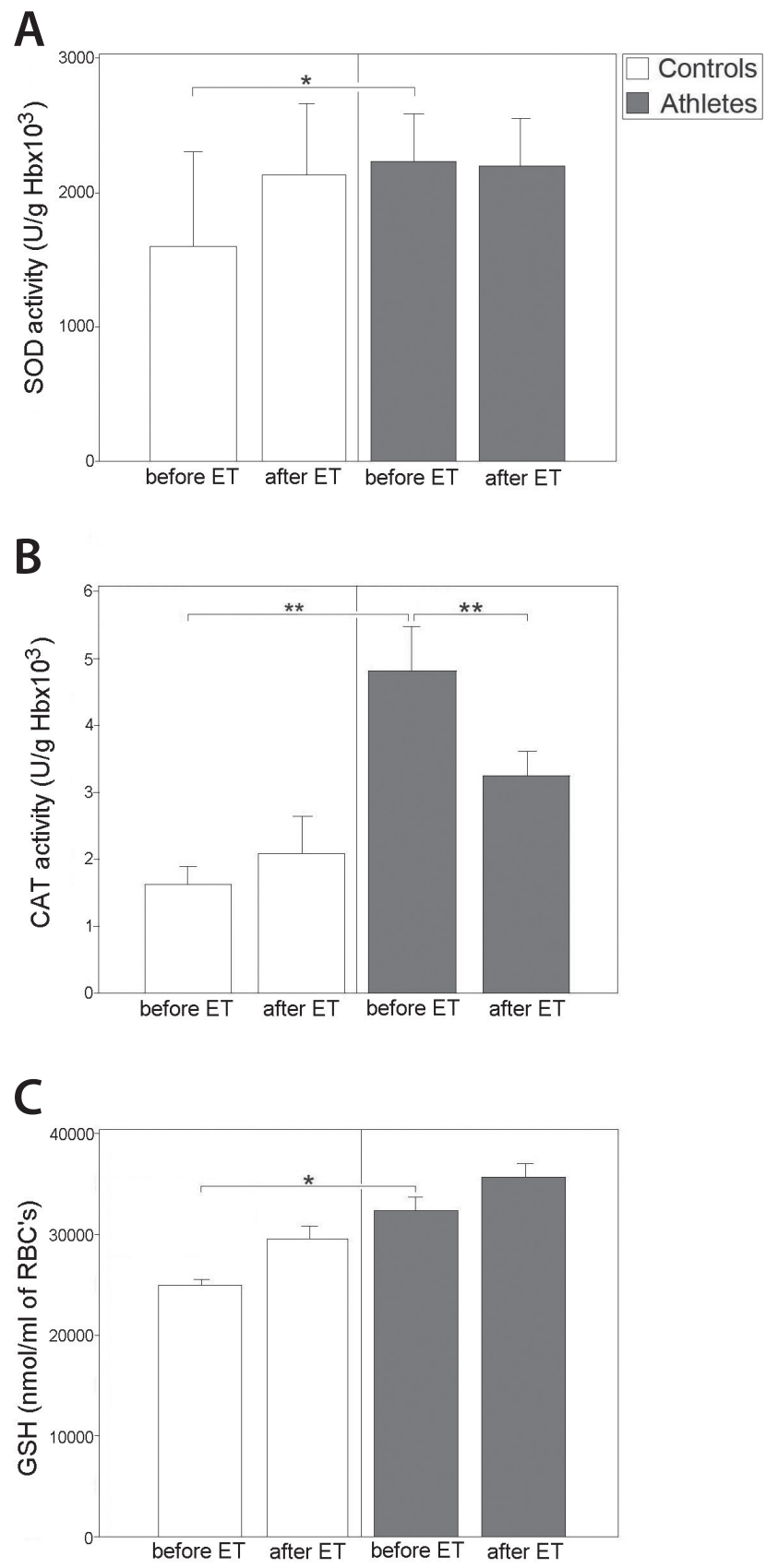

Figure 2. Values of antioxidative parameters: SOD activity (A), CAT activity (B) and GSH $(\mathbf{C})$ in athletes and controls before and after the exercise test. ${ }^{*} p<0.05$; ${ }^{* *} p<0.01$; ET, exercise test; SOD, superoxide dismutase; CAT, catalase; GSH, reduced glutathione. Data were expressed as mean \pm S.E.M.

letes' and non-athletes' pro/antioxidant responses to acute exercise of maximal intensity.

SOD, enzyme of the first line of defence in RBCs was most commonly found to be the one that changes under the influence of both acute and chronic exercise (Miyazaki 
et al. 2001; Groussard et al. 2003; Ookwara et al. 2003) and the one that differentiates between well trained subjects and controls (Brites et al. 1999; Evelson et al. 2002; Metin et al. 2003). Our study confirmed this observance, since young handball players had significantly higher basal SOD activity compared with non-athletes. We have previously shown that SOD may be a good predictive parameter of the extent of redox homeostasis disturbance induced by an acute bout of exercise (Djordjevic et al. 2010a). In that study we found that in the whole group of investigated athletes maximal graded exercise test induced changes in 5 out of 6 investigated redox parameters (the increase of $\mathrm{H}_{2} \mathrm{O}_{2}, \mathrm{NO}_{2}{ }^{-}$and TBARS levels and the decrease of SOD and CAT activity), but statistical significance of those changes had its roots in the group of athletes with the lowest basal SOD activity (Djordjevic et al. 2010a). It seems that SOD activity determines the effects of exercise on redox homeostasis and that athletes with higher level of basal SOD activity are under lower risk of exercise-induced oxidative stress compared to athletes with low levels of basal SOD activity. This assumption was in part proved in this study. The exercise test induced the statistically significant increase of $\mathrm{O}_{2}{ }^{-}$levels only in non-athletes who, as already mentioned, had lower levels of SOD compared with athletes. Also, after the exercise test, non-athletes had significantly higher levels of $\mathrm{O}_{2}^{-}$compared with athletes. Two-way repeated measures ANOVA showed that exerciseinduced changes of $\mathrm{O}_{2}{ }^{-}$were dependent on sports engagement of subjects.

Higher levels of resting GSH found in athletes compared with non-athletes support the claim that regular exercise training leads towards desirable adaptations of the antioxidant defence system. On the one side regular exercise increases GSH levels (Kretzschmar and Müller 1993; Sen 1999), while on the other side reduced GSH levels are connected with aging and pathology of numerous liver, lung and neurodegenerative diseases (Samiec et al. 1998; Rahman and MacNee 2000; Shulz et al., 2000). GSH both directly and indirectly (as a cofactor for glutathione peroxidase (GPx)) eliminates free radicals (Masella et al. 2005). CAT and GPx are both engaged in $\mathrm{H}_{2} \mathrm{O}_{2}$ elimination, but their affinity for $\mathrm{H}_{2} \mathrm{O}_{2}$ is different and dose-dependent. Affinity of GPx for $\mathrm{H}_{2} \mathrm{O}_{2}$ is higher at low $\mathrm{H}_{2} \mathrm{O}_{2}$ levels, while CAT's affinity rises with the increase of $\mathrm{H}_{2} \mathrm{O}_{2}$ levels. Non-athletes in our study experienced a significant rise of $\mathrm{H}_{2} \mathrm{O}_{2}$ with exercise, but neither GSH levels nor CAT activity changed significantly. On the other hand, athletes did not experience the rise in $\mathrm{H}_{2} \mathrm{O}_{2}$ production, but CAT activity was decreased after exercise test. It may be that increased $\mathrm{H}_{2} \mathrm{O}_{2}$ production in non-athletes is a consequence of their less efficient ADS, while athletes' significantly higher basal GSH levels and CAT activity provided efficient elimination of excess exercise-produced $\mathrm{H}_{2} \mathrm{O}_{2}$. Subjects with a favourable blood GSH redox status at rest maintain a more favourable redox status in response to exercise-induced oxidative stress (Laaksonen et al. 1999).

Resting TBARS levels of athletes in this study were significantly lower than resting TBARS levels of non-athletes. Since blood GSH was shown to be a determinant of plasma TBARS at rest (Laaksonen et al. 1999), we hypothesize that lower resting TBARS levels in athletes compared with non-athletes are a consequence of significantly higher GSH levels in athletes' blood. Maximal exercise test induced the fall of TBARS levels in group of non-athletes, which was quite unexpected if taken into consideration the behaviour of other three prooxidative parameters. Namely, levels of $\mathrm{O}_{2}{ }^{-}, \mathrm{H}_{2} \mathrm{O}_{2}$ and $\mathrm{NO}\left(\mathrm{NO}_{2}{ }^{-}\right)$increased after exercise test in group of non-athletes, but although the reactions between $\mathrm{O}_{2}{ }^{-}$and other two prooxidants may lead towards formation of hydroxyl radical, a powerful inducer of lipid peroxidation, TBARS as index of lipid peroxidation was decreased. In contrast to results of our previous study on another group of young handball players which found that athletes with higher $\mathrm{VO}_{2}$ max had higher levels of resting TBARS levels (Djordjevic et al. 2011), results of this study point to a negative correlation between $\mathrm{VO}_{2}$ max and resting TBARS levels. Negative correlations between $\mathrm{VO}_{2}$ max and TBARS both before and after the exercise test, as well as negative correlation between $\mathrm{VO}_{2}$ max and $\mathrm{H}_{2} \mathrm{O}_{2}$ resting levels and positive correlation between $\mathrm{VO}_{2} \max$ and resting CAT activity support the hypothesis that aerobic power correlates positively with desirable redox state. Correlations between body composition and redox parameters found in this study also support this, since body composition can be classified as a health related physical fitness component (Thompson et al. 2009).

Athletes in our study had significantly higher basal levels of NO compared with non-athletes. It is in accordance with numerous previous studies that showed that regular physical activity increases the bioavailibity of NO (Jungersten et al. 1997; Kingwell et al. 1997; Lewis et al. 1999; Maeda et al. 2001; Maiorana et al. 2003; Mendes-Ribeiro et al. 2009) and that physically active people have greater basal NO production compared with a sedentary population (Poveda et al. 1997; Green et al. 2004; Banfi et al. 2006). Studies that investigated the effects of acute exercise on NO production yielded various results. Some studies reported NO increase with exercise, some reported no change in NO production and some reported a decrease in NO production with exercise (Jungersten et al. 1997; Poveda et al. 1997; St. Croix et al. 1999; Allen et al. 2006; Allen et al. 2009; Rassaf et al. 2007; Djordjevic et al. 2010a,b; Cubrilo et al. 2011; Jakovljevic et al. 2011). Those differences are probably due to different protocols, i.e. different characteristics of subjects (age, physical activity, health), different training and tests (type, intensity, duration of exercise tests or training), various methods of measuring RONS production, etc. The exercise test in this research induced the fall in 
$\mathrm{NO}\left(\mathrm{NO}_{2}{ }^{-}\right)$production in athletes but the rise of $\mathrm{NO}\left(\mathrm{NO}_{2}{ }^{-}\right)$ levels in non-athletes. Two-way repeated measures ANOVA showed that exercise-induced changes of $\mathrm{NO}\left(\mathrm{NO}_{2}{ }^{-}\right)$were dependent on sports engagement of subjects. The rise of $\mathrm{NO}$ $\left(\mathrm{NO}_{2}{ }^{-}\right)$levels in non-athletes may be explained by effects of shear stress, while the response of athletes may be explained by endothelium preconditioning achieved by chronic exposure to shear stress during exercise trainings and i.e. structural and functional adaptations of endothelium (Kingwell 2000; Tinken et al. 2008; Bauer and Sotnikova 2010). It seems that the effects of chronic exercise on the basal NO production are more important than effects of NO production on tolerance of physical activity.

It should be noticed that there was statistically significant difference in total exercise test time and load between athletes and non-athletes, which may be the reason for observed biochemical responses, but the aim of our study was to assess the effects of a maximal exercise test, and the test was maximal for every participant. The differences in redox status post exercise are probably a function of the exercise-induced mechanical damage to muscle fibres and the subsequent inflammatory cascade in unaccustomed subjects.

The results of this study show that athletes are under lower risk of redox state disturbance both at rest and after exercise. Oxidative stress induces oxidative damage and inflammation, and it has been suggested to play a primary or secondary role in the development of more than a hundred acute and chronic human diseases. The results of our study suggest that improving physical fitness may be the way to improve the antioxidant defense and to preserve the health of an individual.

Acknowledgements: This work was supported by grant No. 175043 from the Ministry of Science and Technical Development of the Republic of Serbia.

\section{References}

Allen J. D., Cobb F. R., Kraus W. E., Gow A. J. (2006): Total nitrogen oxide following exercise testing reflects endothelial function and discriminates health status. Free Radic. Biol. Med. 41, 740-747 http://dx.doi.org/10.1016/j.freeradbiomed.2006.05.016

Allen J. D., Miller E. M., Schwark E., Robbins J. L., Duscha B. D., Annex B. H. (2009): Plasma nitrite response and arterial reactivity differentiate vascular health and performance. Nitric Oxide 20, 231-237

http://dx.doi.org/10.1016/j.niox.2009.01.002

Allen R. G., Tresini M. (2000): Oxidative stress and gene regulation. Free Radic. Biol. Med. 28, 463-499 http://dx.doi.org/10.1016/S0891-5849(99)00242-7

Auclair C., Voisin E. (1985): Nitroblue tetrazolium reduction. In: Handbook of methods for oxygen radical research. (Ed. R. A. Greenvvald), pp. 123-132, Boka Raton, CRC Press, Greenvvald Ine
Balakrishnan S. D., Anuradh C. V. (1998): Exercise, depletion of antioxidants and antioxidant manipulation. Cell. Biochem. Funct. 16, 269-275

http://dx.doi.org/10.1002/(SICI)1099-0844(1998120)16:4<269:: AID-CBF797>3.0.CO;2-B

Banfi G., Malavazos A., Iorio E., Dolci A., Doneda L., Verna R., Corsi M. M. (2006): Plasma oxidative stress biomarkers, nitric oxide and heat shock protein 70 in trained elite soccer players. Eur. J. Appl. Physiol. 96, 483-486 http://dx.doi.org/10.1007/s00421-005-0104-6

Bauer V., Sotnikova R. (2010): Nitric oxide - the endotheliumderived relaxing factor and its role in endothelial functions. Gen. Physiol. Biophys. 29, 319-340 http://dx.doi.org/10.4149/gpb_2010_04_319

Beutler E. (1975): Reduced glutathione (GSH). In: Red Cell Metabolism, a Manual of Biochemical Methods. (Ed. E. Beutler), pp. 112-114, Grune and Stratton, New York

Beutler E. (1982): Catalase. In: Red Cell Metabolism, a Manual of Biochemical Methods. (Ed. E. Beutler), pp. 105-106, Grune and Stratton, New York

Block G., Dietrich M., Norkus E. P., Morrow J. D., Hudes, M., Caan, B., Packer, L. (2002): Factors associated with oxidative stress in human populations. Am. J. Epidemiol. 156, 274-285 http://dx.doi.org/10.1093/aje/kwf029

Borg G. A. (1982): Psychophysical bases of perceived exertion. Med. Sci. Sports Exerc. 14, 377-381 http://dx.doi.org/10.1249/00005768-198205000-00012

Brites F. D., Evelson P. A., Christiansen M. G., Nicol M. F., Basílico M. J., Wikinski R. W., Llesuy S. F. (1999): Soccer players under regular training show oxidative stress but an improved plasma antioxidant status. Clin. Sci. 96, 381-385

http://dx.doi.org/10.1042/CS19980269

Cazzola R., Russo-Volpe S., Cervato G., Cestaro B. (2003): Biochemical assessments of oxidative stress, erythrocyte membrane fluidity and antioxidant status in professional soccer players and sedentary controls. Eur. J. Clin. Investig. 33, 924-930 http://dx.doi.org/10.1046/j.1365-2362.2003.01227.x

Cooper C. E., Vollard N. B. J., Choueiri T., Wilson M. T. (2002): Exercise, free radicals and oxidative stress. Biochem. Soc. Trans. 30, 280-285 http://dx.doi.org/10.1042/BST0300280

Cubrilo D., Djordjevic D., Zivkovic V., Djuric D., Blagojevic D., Spasic M., Jakovljevic V. (2011): Oxidative stress and nitrite dynamics under maximal load in elite athletes: relation to sport type. Mol. Cell. Biochem. 355, 273-279 http://dx.doi.org/10.1007/s11010-011-0864-8

Dalle-Donne I., Rossi R., Colombo R., Giustarini D., Milzani A. (2006): Biomarkers of oxidative damage in human disease. Clin. Chem. 52, 601-623 http://dx.doi.org/10.1373/clinchem.2005.061408

Djordjevic D., Cubrilo D., Zivkovic V., Barudzic N., Vuletic M., Jakovljevic V. (2010a): Pre-exercise superoxide dismutase activity affects the pro/antioxidant response to acute exercise. Ser. J. Exp. Clin. Res. 11, 145-153

Djordjevic D., Jakovljevic V., Cubrilo D., Zlatkovic M., Zivkovic V., Djuric D. (2010b): Coordination between nitric oxide and superoxide anion radical during progressive exercise in elite soccer players. Open Biochem. J. 4, 100-106 
http://dx.doi.org/10.2174/1874091X01004010100

Djordjevic D., Cubrilo D., Macura M., Barudzic N., Djuric D., Jakovljevic V. (2011): The influence of training status on oxidative stress in young male handball players. Mol. Cell. Biochem. 351, 251-259 http://dx.doi.org/10.1007/s11010-011-0732-6

Dröge W. (2002): Free radicals in the physiological control of cell function. Physiol. Rev. 82, 47-95

Evelson P., Gambino G., Travacio M., Jaita G., Verona J., Maroncelli C., Wikinski R., Llesuy S., Brites F. (2002): Higher antioxidant defenses in plasma and low density lipoproteins from rugby players. Eur. J. Clin. Invest. 32, 818-825 http://dx.doi.org/10.1046/j.1365-2362.2002.01057.x

Fanò G., Mecocci P., Vecchiet J., Belia S., Fulle S., Polidori M. C., Felzani G., Senin U., Vecchiet L., Beal M. F. (2001): Age and sex influence on oxidative damage and functional status in human skeletal muscle. J. Muscle Res. Cell. Motil. 22, 345-351 http://dx.doi.org/10.1023/A:1013122805060

Finaud J., Lac G., Filaire E. (2006): Oxidative stress: relationship with exercise and training. Sports Med. 36, 327-358 http://dx.doi.org/10.2165/00007256-200636040-00004

Fisher-Wellman K., Bloomer R. J. (2009): Acute exercise and oxidative stress: a 30 year history. Dyn. Med. 8, 1-25 http://dx.doi.org/10.1186/1476-5918-8-1

Goldfarb A. H., McKenzie M. J., Bloomer R. J. (2007): Gender comparisons of exercise-induced oxidative stress: influence of antioxidant supplementation. Appl. Physiol. Nutr. Metab. 32, 1124-1131 http://dx.doi.org/10.1139/H07-078

Gougoura S., Nikolaidis M. G., Kostaropoulos I. A., Jamurtas A. Z., Koukoulis G., Kouretas D. (2007): Increased oxidative stress indices in the blood of child swimmers. Eur. J. Appl. Physiol. 100, 235-239 http://dx.doi.org/10.1007/s00421-007-0423-x

Green L. C., Wagner D. A., Glogowski J., Skipper P. L., Wishnok J. S., Tannenbaum S. R. (1982): Analysis of nitrate, nitrite and $[15 \mathrm{~N}]$ nitrate in biological fluids. Anal. Biochem. 126, $131-138$ http://dx.doi.org/10.1016/0003-2697(82)90118-X

Green D. J., Maiorana A., O’Driscoll G., Taylor R. (2004): Effect of exercise training on endothelium-derived nitric oxide function in humans. J. Physiol. 561, 1-25 http://dx.doi.org/10.1113/jphysiol.2004.068197

Groussard C., Rannou-Bekono F., Machefer G., Chevanne M., Vincent S., Sergent O., Cillard J., Gratas-Delamarche A. (2003): Changes in blood lipid peroxidation markers and antioxidants after a single sprint anaerobic exercise. Eur. J. Appl. Physiol. 89, $14-20$ http://dx.doi.org/10.1007/s00421-002-0767-1

Howley E. T., Bassett D. R. Jr, Welch H. G. (1995): Criteria for maximal oxygen uptake: review and commentary. Med. Sci. Sports Exerc. 27, 1292-1301 http://dx.doi.org/10.1249/00005768-199509000-00009

Jacob C., Winyard P. G. (2009): Introduction. In: Redox Signaling and Regulation in Biology and Medicine. (Eds. Jacob C.and Winyard P. G.), Wiley-VCH Verlag Gmbh \& Co., Weinheim http://dx.doi.org/10.1002/9783527627585.ch1
Jakovljevic V. Lj., Zlatkovic M., Cubrilo D., Pantic I., Djuric D. M. (2011): The effects of progressive exercise on cardiovascular function in top level athlets: Focus on oxidative stress. Acta Physiol. Hung. 98, 50-57 http://dx.doi.org/10.1556/APhysiol.98.2011.1.7

Ji L. L. (2002): Exercise-induced modulation of antioxidant defense. Ann. N.Y. Acad. Sci. 959, 82-92 http://dx.doi.org/10.1111/j.1749-6632.2002.tb02085.x

Jungersten L., Ambring A., Wall B., Wennmalm A. (1997): Both physical fitness and acute exercise regulate nitric oxide formation in healthy humans. J. Appl. Physiol. 82, 760-764

Juranek I., Bezek S. (2005): Controversy of free radical hypothesis: reactive oxygen species - cause or consequence of tissue injury? Gen. Physiol. Biophys. 24, 263-278

Kingwell B. A., Sherrard B., Jennings G. L., Dart A. M. (1997): Four weeks of cycle training increases basal production of nitric oxide from the forearm. Am. J. Physiol. 272, H1070-1077

Kingwell B. A. (2000): Nitric oxide-mediated metabolic regulation during exercise: effects of training in health and cardiovascular disease. FASEB J. 14, 1685-1696 http://dx.doi.org/10.1096/f.99-0896rev

Kretzschmar M., Müller D. (1993): Aging, training and exercise. A review of effects on plasma glutathione and lipid peroxides. Sports Med. 15, 196-209 http://dx.doi.org/10.2165/00007256-199315030-00005

Laaksonen D. E., Atalay M., Niskanen L., Uusitupa M., Hänninen O., Sen C. K. (1999): Blood glutathione homeostasis as a determinant of resting and exercise-induced oxidative stress in young men. Redox Rep. 4, 53-59 http://dx.doi.org/10.1179/135100099101534648

Lewis T., Dart A. M., Chin-Dusting J. P. F., Kingwell B. A. (1999): Exercise training increases basal nitric oxide production from the forearm in hypercholesterolemic patients. Arterioscler. Thromb. Vasc. Biol. 19, 2782-2787 http://dx.doi.org/10.1161/01.ATV.19.11.2782

Lim J. S., Hwang J. S., Lee J. A., Kim D. H., Park K. D., Jeong J. S., Cheon G. J. (2009): Cross-calibration of multi-frequency bioelectrical impedance analysis with eight-point tactile electrodes and dual-energy X-ray absorptiometry for assessment of body composition in healthy children aged $6-18$ years. Pediatr. Int. 51, 63-68

Maeda S., Miyauchi T., Kakiyama T., Sugawara J., Iemitsu M., Irukayama-Tomobe Y., Murakami H., Kumagai Y., Kuno S., Matsuda M. (2001): Effects of exercise training of 8 weeks and detraining on plasma levels of endothelium-derived factors, endothelin-1 and nitric oxide in healthy young humans. Life Sci. 69, 1005-1016 http://dx.doi.org/10.1016/S0024-3205(01)01192-4

Maiorana A., O’Driscoll G., Taylor R., Green D. (2003): Exercise and the nitric oxide vasodilator system. Sports Med. 33, 1013-1035 http://dx.doi.org/10.2165/00007256-200333140-00001

Masella R., Di Benedetto R., Vari R., Filesi C., Giovannini C. (2005): Novel mechanisms of natural antioxidants compounds in biological systems. Involvement of glutathione and glutathione related enzymes. J. Nutrit. Biochem. 16, 577-586 http://dx.doi.org/10.1016/j.jnutbio.2005.05.013 
McCord J. M., Fridovich I. (1969): The utility of superoxide dismutase in studying free radical reactions. Radicals generated by the interaction of sulfite, dimethyl sulfoxide, and oxygen. J. Biol. Chem. 244, 6056-6063

Mendes-Ribeiro A. C., Mann G. E., de Meirelles L. R., Moss M. B., Matsuura C., Brunini T. M. C. (2009): The role of exercise on $\mathrm{L}$-arginine nitric oxide pathway in chronic heart failure. Open Biochem. J. 3, 55-65 http://dx.doi.org/10.2174/1874091X00903010055

Metin G., Gümüştaş M. K., Uslu E., Belce A., Kayserilioglu A. (2003): Effect of regular training on plasma thiols, malondialdehyde and carnitine concentrations in young soccer players. Chin. J. Physiol. 46, 35-39

Misra H. P., Fridovich I. (1972): The role of superoxide-anion in the autooxidation of epinephrine and a simple assay for superoxide dismutase. J. Biol. Chem. 247, 3170-3175

Miyazaki H., Oh-ishi S., Ookawara T., Kizaki T., Toshinai K., Ha S., Haga S., Ji L. L., Ohno H. (2001): Strenuous endurance training in humans reduces oxidative stress following exhausting exercise. Eur. J. Appl. Physiol. 84, 1-6 http://dx.doi.org/10.1007/s004210000342

Møller P., Wallin H., Knudsen L. E. (1996): Oxidative stress associated with exercise, psychological stress and life-style factors. Chem. Biol. Interact. 102, 17-36 http://dx.doi.org/10.1016/0009-2797(96)03729-5

Nieman D. C., Austin M. D., Benezra L., Pearce S., McInnis T., Unick J., Gross S. J. (2006): Validation of Cosmed's FitMate in measuring oxygen consumption and estimating resting metabolic rate. Res. Sports Med. 14, 89-96 http://dx.doi.org/10.1080/15438620600651512

Nieman D. C., Lasasso H., Austin M. D., Pearce S., McInnis T., Unick J. (2007): Validation of Cosmed's FitMate in measuring exercise metabolism. Res. Sports Med. 15, 67-75 http://dx.doi.org/10.1080/15438620601184380

Ohkawa H., Ohishi N., Yagi K. (1979): Assay for lipid peroxides in animal tissues by thiobarbituric acid reaction. Anal. Biochem. 95, 351-358 http://dx.doi.org/10.1016/0003-2697(79)90738-3

Ørtenblad N., Madsen K., Djurhuus M. S. (1997): Antioxidant status and lipid peroxidation after short-term maximal exercise in trained and untrained humans. Am. J. Physiol. 272, R1258-1263

Pick E., Keisari Y. (1980): A simple colorimetric method for the measurement of hydrogen peroxide produced by cells in culture. J. Immunol. Methods 38, 161-170 http://dx.doi.org/10.1016/0022-1759(80)90340-3

Poveda J. J., Riestra A., Salas E., Cagigas M. L., López-Somoza C., Amado J. A., Berrazueta J. R. (1997): Contribution of nitric oxide to exercise-induced changes in healthy volunteers: effects of acute exercise and long-term physical training. Eur. J. Clin. Invest. 27, 967-971 http://dx.doi.org/10.1046/j.1365-2362.1997.2220763.x

Powers S. K., Duarte J., Kavazis N., Talbert E. (2009): Reactive oxygen species are signalling molecules for skeletal muscle adaptation. Exp. Physiol. 95, 1-9 http://dx.doi.org/10.1113/expphysiol.2009.050526
Radak Z., Chung H. Y., Koltai E., Taylor A. W., Goto S. (2008): Exercise, oxidative stress and hormesis. Ageing Res. Rev. 7, $34-42$ http://dx.doi.org/10.1016/j.arr.2007.04.004

Rahman I., MacNee. W. (2000): Oxidative stress and regulation of glutathione in lung inflammation. Eur. Respir. J. 16, 534-554 http://dx.doi.org/10.1034/j.1399-3003.2000.016003534.x

Rassaf T., Lauer T., Heiss C., Balzer J., Mangold S., Leyendecker T., Rottler J., Drexhage C., Meyer C., Kelm M. (2007): Nitric oxide synthase-derived plasma nitrite predicts exercise capacity. Br. J. Sports Med. 41, 669-673 http://dx.doi.org/10.1136/bjsm.2007.035758

Samiec P. S., Drews-Botsch C., Flagg E. W., Kurtz J.C., Sternberg P. Jr, Reed R. L., Jones D. P. (1998): Glutathione in human plasma: decline in association with aging, age-related macular degeneration, and diabetes. Free Radic. Biol. Med. 24, 699-704 http://dx.doi.org/10.1016/S0891-5849(97)00286-4

Sen C. K. (1999): Glutathione homeostasis in response to exercise training and nutritional supplements. Mol. Cell. Biochem. 196, 31-42 http://dx.doi.org/10.1023/A:1006910011048

St. Croix C. M., Wetter T. J., Pegelow D. F., Meyer K. C., Dempsey J. A. (1999): Assessment of nitric oxide formation during exercise. Am. J. Respir. Crit. Care Med. 159, 1125-1133

Szocs K. (2004): Endothelial dysfunction and reactive oxygen species production in ischemia/reperfusion and nitrate tolerance. Gen. Physiol. Biophys. 23, 265-295

PMid:15638116

Thompson W. R., Gordon N. F., Pescatello L. S., et al. (2009): ACSM's guidelines for exercise testing and prescription. (8th edition), Lippincott Williams \& Wilkins

Tiidus P. M. (1998): Radical species in inflammation and overtraining. Can. J. Physiol. Pharmacol. 76, 533-538

http://dx.doi.org/10.1139/y98-047

Tinken T. M., Thijssen D. H. J., Black M. A., Cable N. T., Green D. J. (2008): Time course of change in vasodilator function and capacity in response to exercise training in humans. J. Physiol. 586, 5003-5012 http://dx.doi.org/10.1113/jphysiol.2008.158014

Valko M., Leibfritz D., Moncol J., Cronin M. T., Mazur M., Telser J. (2007): Free radicals and antioxidants in normal physiological functions and human disease. Int. J. Biochem. Cell. Biol. 39, $44-84$ http://dx.doi.org/10.1016/j.biocel.2006.07.001

Vollaard N. B., Shearman J. P., Cooper C. E. (2005): Exerciseinduced oxidative stress: myths, realities and physiological relevance. Sports Med. 35, 1045-1062 http://dx.doi.org/10.2165/00007256-200535120-00004

Yamaner F. (2010): Oxidative predictors and lipoproteins in male soccer players. Turk. J. Med. Sci. 40, 1-8

Tsuchihashi M. (1923): Zur kernntnis der blutkatalase. Biochem. Z. 140, 65-72

Received: November 9, 2011

Final version accepted: January 25, 2012 